\title{
The Sociology of Battered Women
}

\author{
Babita Tewari \\ Chhatrapati Shahu Ji Maharaj University \\ Kanpur, Uttar Pradesh, India.
}

\begin{abstract}
This paper undertakes to examine the hitherto neglected but nevertheless important area of Research, the Sociology of Battered Women. As there are very few researches in Sociological Literature in this area, particularly in the Indian perspective, hence a study in this direction in Kanpur City was carried out. The analysis reveals the diverse factors which lead to wife battering such as the age, religion, caste, educational background, rural or urban background, childbearing, sex, dowry, male child, economical status, dominance of in-laws, etc. The study explores that despite the various empowerment and emancipation strategies adopted by the different sectors of society for women, the ghastly reality still persists that what so ever be the religion, caste, background of the women, they are being tortured and battered even today. The basic causes behind this being the prevalence of male domination \& patriarchal systems, gender discrimination, social dependency and unequal power relations. This social devil can be eliminated only and only after the women gain political and economic power.
\end{abstract}

Keywords : Wife battering, women empowerment, gender discrimination

\section{INTRODUCTION}

It is a matter of deep concern that even after five decades of the adoption of the Constitution of India, which provides equality to sexes, the status of women continues to be subordinate and inferior to that of man in the Indian Society. Despite several Legal measures aimed at ameliorating women's status and also despite the massive efforts of Women's Organisation to improve the lot of women, the Indian women in the beginning of the 21 st Century continues to be physically abused, oppressed and victimised. Violence against women not only continues to exist, but it has assumed disquieting magnitudes .

Remedial measures however, have tended to be symptomatic rather than structural in a society where violence against women is increasing which includes wife beating, rape, dowry deaths, wife burning, suicides and even female foeticide and female infanticide. You may open any Newspaper or tune Television, any day and you will find horrifying reports of how some young girl has been confined to flames for not bringing adequate dowry or how some charming young girl barely in her teens has been made a victim of the lust and sumptuous desires of some wayward youths, or how a future hope of the

* The material presented by the author does not necessarily portray the viewpoint of the editors and the management of the Institute of Business \& Technology (BIZTEK) or Chhatrapati Shahu Ji Maharaj University, Kanpur, Uttar Pradesh, India.

*Babita Tewari : babita.tewari@yahoo.co.in

(C) JMSS is published by the Institute of Business and Technology (BIZTEK). Main Ibrahim Hydri Road, Korangi Creek, Karachi-75190, Pakistan. 
Nation has been compelled to embrace flames over the pyre of her husband. There are thousand of incidents where women are terrorised and even killed for being unable to produce a male child. Parental preferences for male child gives rise to female foeticides. J.B.D'Souza reports that of 8000 abortions that followed sex determination tests only one involved a male foetus, i.e. $7999: 1$ ratio (Times of India, 11 Jan, 2006 ).

It is not peculiar to India alone. Violence against women has always existed but its cognition and articulation is a relatively new phenomenon. Even today all aspects of this violence are not taken cognizance of although the process is continuing with alacrity.

Perhaps it is not altogether incorrect to say that themes such as exploitation of women, inequality between men and women, violence against women gained visibility in India only by the mid 70's. Several factors facilitated this perception and articulation. The look towards equality in 1975 and the International Women's Decade beginning the very same year were undoubtedly the first definitive instruments in awakening conscientiousness amongst all of us. The oppression of women is reflected in the status and role of women in the Social, Political and Economic systems but its roots are found in History and Culture. A glimpse into the historical circumstances which were responsible for the centuries old suppression of women in Indian society would bear ample testimony to the above statement.

The subjugation and subordination of women was perpetuated by denying her Education, Income and Inheritance. She herself was treated as a piece of property to reinforce the authority of the husband over wife. A wide gap between the ages of the bride and the groom also existed. Violence against women, like all other historical phenomenon of violence, must be seen in a socio-economic and political context of power-relation. It is produced within a class-caste gendered society in which the male power dominates.

The present study is conducted on women belonging to lower class and middle class. A monthly income of Rs.3000/- or less of the women and their husbands have been categorised as 'lower class' and a monthly income of Rs.3000/- or more have been earmarked as 'middle class'. The lower class women basically imbibes those who are engaged in cooking, washing utensils, cleaning clothes etc. whereas the middle class women are those who belong to service class, are self employed with income of more than Rs.3000/- per month or whose husbands also are well off. It was indeed a daunting experience for me as interviewing women from the middle strata who had been living with their husbands and in-laws was extremely sensitive and difficult. The study is an attempt to dig out the wide-ranging factors responsible for wife battering and also a manifestation to find a solution.

\section{HISTORICAL DEVELOPMENT OF WOMEN'S STATUS}

The status of women in Indian society has undergone changes at different historical levels. In the pre-Vedic Aryan period, the status of women was quite superior. The matriarchal system of society was prevalent in those times which changed to patriarchal in the Vedic period. It was in the Vedic era that issues such as character and sacredness were being discussed. However, the position of women in the Vedic period too was satisfactory, but the same deteriorated after the Vedic age. The women in times of Manu Smriti were treated as Goddess, but practically they did not get the proper respect. In their childhood, they were dependent on their Father, in their youth on their husbands and in their old age on their sons. The women were not authorised to enchant Vedic Mantras and rhymes. They were de facto jailed in their houses. As a consequence of all these, the women gradually lost sight of the society and paved way for the patriarchal system. The same women, which was purported to perform the final ritual rights of her father such as Shraadha, was replaced by the son. The women was treated as untouchables after giving birth to a child, during the periods of menses, and were looked upon negligently if they did not produce a male child. The standing of women during the Muslim rule of India tarnished even further. In order to prevent Hindu women falling in to the hands of Muslim rulers, customs such as Child Marriage and Purdah were introduced. However, the British did not damage the 
sociological systems prevalent amongst women but on the contrary initiated projects such as modern education, missionaries etc. for their uplifting. Reformers such as Raja Ram Mohan Roy, Dayanand Saraswati, Govind Ranade fought for the cause of the women. During the Indian Freedom struggle movement, many measures were adopted for ameliorating the significance of women. Even after the Independence and formulation of the Indian Constitution, many strategic and consequential instruments were provided to women for their elevation. The Indian Penal Code was also enriched with penetrative sections to safeguard the interest of the women apart from the participation of women in the political and economic sectors.

\section{THEORETICAL ISSUES REGARDING VIOLENCE AGAINST WOMEN}

There is an asymmetrical relationship between the husband and the wife due to the Patriarchal system and male domination. The social violence against women is primarily based on social or institutional structure of the patriarchal order perpetrating all kinds of discrimination and oppression of women which results in to behavioural violence. It has been analysed that when women have no rights of land ownership, they are taken to be non entities and are treated as only sex objects.

The other important issue directly affecting violence against women is the Gender discrimination. The present paper has also made an attempt to capture the reasons for battering despite the fact that women of today are excelling and equalling in all spheres of life along with men. Both the husband and the wife are working, but the women still has to do the household jobs such as cooking, looking after children, cleaning the house etc. The entire responsibility of managing household affairs is of the women. This is due to the gender discrimination. The principal cause behind this, which reveals from the study is the male domination because of the political and economical power which the women of today is yet to acquire. In most of the societies including Indian society, women is victim of gender discrimination and gender discrimination not only implies low status of women but it also discriminates between roles of men and women. Traditionally, and in most of the societies, even now, women's role are mostly confined to bearing and wearing of children, household chores like cooking, washing, cleaning the house etc. For a very long time, she was denied education, political roles, and even economic functions. Despite the multiple opportunity structure, which is now available to the women, she still cannot leave her traditional roles. If a wife is working outside the home, she is encouraged by her husband and in-laws as she is adding to the income of the family. Nevertheless, she cannot ignore her traditional roles of cooking, looking after children, cleaning the house etc. She is the victim of this dilemma of performing two roles.

Yet another fundamental factor is the Social dependency of the women on the men. The interviews of so many women made it known that women suffer atrocities at the hands of their husbands due to economic dependency on their husbands as they have no way out to resolve this issue. The dependency, at times, is not only due to financial reasons, but also due to a fear psychosis that they will not find a respectable position in the society and will be treated as dejected and disregarded. The maintenance of herself, her children and the above narrated factors compel her to lead a gloomy life.

\section{METHODOLOGY}

The research design is partial exploratory and partial experimental. It is exploratory as a number of hypotheses have emerged from the study for further verification and future research. It is highly experimental as it is a comparative study among middle and lower class women. Not much exploration has been done in India in this field and as such hypotheses have been developed to form a base of the study and formulation of future strategies. Exploratory Research is necessary to obtain the experience which will be helpful in formulating relevant hypotheses for more definite investigation ( Johode, 1951). The concept of experimental design in sociological research refers to the systematic study of 
human relations by making observations under conditions of control ( Chapin, 1935). The prime objective of the research was to analyse wife battering, particularly in context to middle class women but in order to understand the depth of the problem, studies of atrocities on women from lower class were also effectuated. As most of the women lived in joint families, it became intricate to know about the battering. Hence, the snow-ball technique was used to find cases. 75 women from middle class and 75 from lower class were selected. In case of any information of battered women pouring in, the same was interviewed and occasionally more information was gathered for likewise cases. Besides this, some studies of dowry, violence etc. were also conducted through cases derived from newspapers.

An interview schedule was prepared containing 100 questions based on husband's family, educational background, occupation, marriage relations, custom of marriage, whether dowry had been demanded at the time of marriage, whether dowry was given at the time of solemnisation of marriage, family planning, sexual relations between the husband and the wife, balancing of relations, incidences of quarrelling and tensions between husband and wife and as to when and how it started, the role of in-laws in jeopardising the cordial relations, etc.

\section{SOCIAL BACKGROUND OF THE RESPONDENTS}

In order to gauge the level of battering, it was imperative to study the social environment of the women such as their age, religion, caste, background (urban or rural), tenure at Kanpur, educational altitude, their husband's age and their educational backdrop etc.

Table. 1

\begin{tabular}{|l|c|c|c|c|}
\hline \multirow{2}{*}{ Age of Respondents (in vears) } & \multicolumn{2}{|c|}{ Middle Class Women } & \multicolumn{2}{l|}{ Lower Class Women } \\
\hline & Number & \%age & Number & \%age \\
\hline $18-25$ & 13 & 17.3 & 17 & 22.6 \\
\hline $25-30$ & 21 & 28.0 & 23 & 30.6 \\
\hline $30-35$ & 21 & 28.0 & 19 & 25.3 \\
\hline $35-40$ & 15 & 20.0 & 16 & 21.3 \\
\hline Above 40 & 05 & 06.6 & Nil & Nil \\
\hline Religion of Respondents & & & & \\
\hline Hindu & 59 & 79.6 & 55 & 73.2 \\
\hline Muslim & 08 & 10.6 & 08 & 10.6 \\
\hline Christian & 04 & 5.3 & 04 & 5.3 \\
\hline Sikh & 04 & 5.3 & 08 & 10.6 \\
\hline Background & & & & \\
\hline Rural & 07 & 9.3 & 26 & 34.6 \\
\hline Urban & 68 & 90.3 & 49 & 65.3 \\
\hline Tenure at Kanpur & & & & \\
\hline Since birth & 44 & 58.6 & 41 & 54.6 \\
\hline For last 20 years & 18 & 24.0 & 15 & 20.0 \\
\hline For last 10 years & 18 & 17.3 & 18 & 24.0 \\
\hline Educational level & & & & \\
\hline Illiterate & Nil & Nil & 21 & 28.0 \\
\hline Can only read/write & 09 & 12.0 & 21 & 28.0 \\
\hline Primary level & 02 & 2.6 & 11 & 14.6 \\
\hline High School & 05 & 6.6 & 09 & 12.0 \\
\hline Intermediate & 08 & 10.6 & 06 & 08.0 \\
\hline Graduate & 37 & 49.3 & 07 & 09.3 \\
\hline Post Graduate & 10 & 13.36 & Nil & Nil \\
\hline Age of Husbands ( in years ) & & & & \\
\hline 18 - 25 & Nil & Nil & 03 & 04.0 \\
\hline 25 - 30 & 18 & 24.0 & 20 & 26.6 \\
\hline $30-35$ & 24 & 32.0 & 23 & 30.6 \\
\hline $35-40$ & 17 & 22.6 & 11 & 14.6 \\
\hline Above 40 & 16 & 21.3 & 18 & 24.0 \\
\hline Husbands education Standards & & & & \\
\hline Illiterate & Nil & Nil & 20 & 26.6 \\
\hline Can only read/write & Nil & Nil & 10 & 13.3 \\
\hline Primary level & Nil & Nil & 15 & 20.0 \\
\hline High School & 10 & 13.3 & 10 & 13.3 \\
\hline Intermediate & 11 & 14.6 & 12 & 16.0 \\
\hline Graduate & 42 & 56.0 & 05 & 06.6 \\
\hline Post Graduate & 08 & 10.6 & 03 & 04.0 \\
\hline & & & & \\
\hline & & & & \\
\hline & & & & \\
\hline
\end{tabular}




\section{THE FAMILY, MARRIED AND ECONOMIC LIFE}

I persevered further for the grassroots of this demonic problem and for this an intensive and a further deep study was required. It was imperative to have an idea about the other co-related factors such as the ages of the married women at the time of marriage, the age of their husbands at the time of marriage, the custom of marriage, the family status, information as to whether dowry had been demanded and further knowledge as to whether the same had been given at the time of marriage, the number of children, whether the married women had a son or not and if not, then the percentage of atrocities, sexual relations, post marital relations of the husbands with other women, economic status etc.

Table. 2

\begin{tabular}{|l|c|c|c|c|}
\hline $\begin{array}{l}\text { Age of Respondents } \\
\text { in years ) at the time of } \\
\text { marriage }\end{array}$ & \multicolumn{2}{l|}{ Middle Class Women } & \multicolumn{2}{l|}{ Lower Class Women } \\
\hline & Number & \%age & Number & \%age \\
\hline $14-18$ & 08 & 10.6 & 29 & 38.6 \\
\hline $18-25$ & 54 & 72.0 & 45 & 60.0 \\
\hline $25-30$ & 11 & 14.0 & 0.1 & 1.3 \\
\hline $30-35$ & 02 & 2.6 & Nil & Nil \\
\hline $\begin{array}{l}\text { Age of their husbands(in } \\
\text { years) at the time of marriage }\end{array}$ & & & & \\
\hline $18-18$ & 11 & 14.6 & 20 & 26.6 \\
\hline $25-30$ & 47 & 62.6 & 49 & 65.3 \\
\hline $30-35$ & 14 & 18.6 & 04 & 5.3 \\
\hline Above 35 & 03 & 4.0 & 2 & 2.6 \\
\hline Custom of marriage & & & & \\
\hline Arranged by family & 67 & 89.0 & 57 & 76.0 \\
\hline Love marriage & 06 & 8.0 & 17 & 22.6 \\
\hline Court marriage & 02 & 2.6 & 01 & 1.3 \\
\hline Family Status & & & & \\
\hline Joint family & 57 & 76.0 & 49 & 65.3 \\
\hline Single family & 18 & 24.0 & 26 & 34.6 \\
\hline Dowry demanded & & & & \\
\hline Yes & 64 & 85.3 & 52 & 69.3 \\
\hline No & 11 & 14.6 & 23 & 30.6 \\
\hline Dowry given & & & & \\
\hline Yes & 66 & 88.0 & 54 & 72.0 \\
\hline No & 09 & 12.0 & 21 & 28.0 \\
\hline No. of children & & & & \\
\hline No children & 32 & 42.6 & 24 & 32.0 \\
\hline one & 20 & 26.6 & 15 & 20.0 \\
\hline two & 18 & 24.0 & 18 & 24.0 \\
\hline three & 04 & 5.3 & 10 & 13.3 \\
\hline Four or more & 28 & 37.3 & 36 & 48.0 \\
\hline Women having Son & & 62.6 & 39 & 52.0 \\
\hline Yes & & & & \\
\hline No & & & & \\
\hline & & & & \\
\hline & & & & \\
\hline
\end{tabular}

\begin{tabular}{|l|c|c|c|c|}
\hline $\begin{array}{c}\text { Whether being battered due } \\
\text { to reason of not having son }\end{array}$ & \multicolumn{2}{|l|}{ Middle Class Women } & \multicolumn{2}{l|}{ Lower Class Women } \\
\hline & Number & \%age & Number & \%age \\
\hline Yes, in-laws usually exploit & 08 & 10.6 & 08 & 10.6 \\
\hline Yes, husband criticises & 06 & 8.0 & 06 & 8.0 \\
\hline Yes, all beat me & 02 & 2.6 & 05 & 6.6 \\
\hline Nobody says anything & 05 & 6.6 & 04 & 5.3 \\
\hline Not applicable & 54 & 72.0 & 52 & 69.3 \\
\hline Extra marital relations & & & & \\
\hline Yes, definitely & 17 & 22.6 & 21 & 28.0 \\
\hline Yes, but suspicious & 05 & 6.6 & Nil & Nil \\
\hline Cannot say & 31 & 41.3 & 36 & 46.0 \\
\hline No & 22 & 29.3 & 18 & 24.0 \\
\hline Economic status & & & & \\
\hline Service/business - yes & 16 & 21.3 & 14 & 18.6 \\
\hline Yes- temporary & 07 & 9.3 & 19 & 25.3 \\
\hline No & 52 & 69.3 & 42 & 56.0 \\
\hline
\end{tabular}




\section{ATROCITIES BY IN-LAWS AND PHYSICAL VIOLENCE ON THE RESPONDENTS}

The level of atrocities and physical violence was also studied such as beating while pregnant, cruelties due to dowry factor, the reasons of wife battering, sexual abuse, etc.

Table. 3

\begin{tabular}{|l|c|c|c|c|}
\hline Wife battering while pregnant & \multicolumn{2}{|l|}{ Middle Class Women } & \multicolumn{2}{l|}{ Lower Class Women } \\
& \multicolumn{2}{l|}{} & \\
\hline & Number & \%age & Number & $\%$ age \\
\hline Yes & 40 & 53.3 & 51 & 68.0 \\
\hline No & 20 & 26.6 & 10 & 13.3 \\
\hline Not applicable & 15 & 20.0 & 14 & 18.6 \\
\hline Dowry related atrocities & & & & \\
\hline Husband never said anything & 08 & 46.6 & 26 & 34.6 \\
\hline Husband usually complains & 31 & 41.3 & 38 & 50.6 \\
\hline
\end{tabular}

\begin{tabular}{|l|c|c|c|c|}
\hline Wife battering while pregnant & \multicolumn{2}{|l|}{ Middle Class Women } & \multicolumn{2}{l|}{ Lower Class Women } \\
& & & \\
\hline & Number & \%age & Number & \%age \\
\hline Yes & 40 & 53.3 & 51 & 68.0 \\
\hline No & 20 & 26.6 & 10 & 13.3 \\
\hline Not applicable & 15 & 20.0 & 14 & 18.6 \\
\hline Dowry related atrocities & & & & \\
\hline Husband never said anything & 08 & 46.6 & 26 & 34.6 \\
\hline Husband usually complains & 31 & 41.3 & 38 & 50.6 \\
\hline
\end{tabular}

\begin{tabular}{|l|c|c|c|c|}
\hline Wife battering while pregnant & \multicolumn{2}{l|}{ Middle Class Women } & \multicolumn{2}{l}{ Lower Class Women } \\
\hline Husband battered only for dowry & Number & $\%$ age & Number & $\%$ age \\
\hline Reasons of wife battering & 09 & 12.0 & 11 & 14.6 \\
\hline For money & & & & \\
\hline Due to in-laws & 01 & 1.3 & 05 & 6.6 \\
\hline Due to women's parents & 02 & 2.6 & 03 & 4.0 \\
\hline Jealousy with wife & 02 & 2.6 & 01 & 1.3 \\
\hline Due to reason of having no & 01 & 1.3 & Nil & Nil \\
children or being less caring & 01 & 1.3 & 03 & 4.0 \\
Non fulfilment of wishes & 03 & 4.0 & 05 & 6.6 \\
\hline Due to misunderstandings & 11 & 14.6 & 03 & 4.0 \\
\hline Husbands high ego & 04 & 5.3 & Nil & Nil \\
\hline Extra marital relations & 17 & 22.6 & 22 & 29.3 \\
\hline Due to consumption of alcohol & 09 & 12.0 & 12 & 16.0 \\
\hline Due to weak economical status & 07 & 9.3 & 02 & 2.6 \\
\hline Due to suspicious nature & 03 & 4.0 & 2 & 2.6 \\
\hline Due to dowry & 14 & 18.6 & 16 & 21.3 \\
\hline Sexual exploitation & & & & \\
\hline No & 60 & 80.0 & 32 & 42.6 \\
\hline Yes & 15 & 20.0 & 43 & 57.3 \\
\hline
\end{tabular}

\section{CONCLUSION}

The analysis reveals that a variety of factors are openly correlated with wife battering. The study banks upon vital aspects such as the age of the respondents, religion, caste, social \& economical background, educational status, the type of families and number of family members, use of contraceptives, number of children, factor of the son, dowry, first marriage or second marriage, post marital relations, the time period till which relations between husband and wife were cordial, the impact of religion on the minds of both the husband and the wife, interference by husbands in matters of wife, questions such as who takes important decisions on household matters, the health situation of both, and if gripped by disease, then the reasons prevailing such malady, frequency and acceptable sexual relations, the monthly incomes, the nature of occupations, the dependency of wife on husband's 
income, use of alcohol by the husbands, the manners of beating, beating during pregnancies, the instruments used for beating, police reporting, the reactions of women on thrashing, etc.

It has been assessed that women prefer living with their partners even after witnessing acute atrocities due to so many latent reasons, basically among them being the apprehension of exclusion from the society. This mental block not only prevents her from raising voices against the cruelties, whatsoever in shape, but at the same time dampens the future prospects of living a life of equality.

\section{REFERENCES}

Ahuja, R 1987. Crime Against Women. Jaipur. Rawat Publications.

Boulding, Elise 1981. Women \& Violence.( 239 - 251 ) Unesco. In violence and its causes. Paris.

Brown, B. 1980. Wife Employment, Marital Equality and Husband Wife Violence. The Social causes of husband wife violence. University of Minnesota Press.

Claire, Safran. 1987. Why men hurt the women they love. Readers Digest.

Dobash \& Dobash. 1980. Violence against wives. London Open Books.

Eisenberg, Micklow. 1977. The Assaulted Wife.: Catch-22 Revisited aja-Abstract of Journal article. Women's Rights. Law Reporter.

Grewal, B. 1982. Family Violence. A case study of slum dwellers of Chandigarh. A dissertation submitted in Deptt. of Sociology, P.U.

Harris, J. 1980. Violence \& Responsibility. Rontledge \& Kegan Paul. London.

Kelkar, Govind. 1985. Women and structural violence in India. Occasional Paper NO. 4.

Kapoor, Pramila. 1970. Marriage and working women in India. Vikas Publication. New Delhi.

Kakkar, S. 1974. Aggression in Indian Society.( 119 - 126 ) An Analysis of Folk Tales : India Journal of Psychology 44. IPA 8:101

Mahajan, A. 1986. Wife beating as instrumental violence. NPCD - Newsletter.

Roy, M. 1977. A current survey of 150 cases. Battered Women. New York.

Sinha, Niroj. 1989. Women \& Violence. Vikas Publication . New Delhi.

Sinha, Archana. 1989. Conceptual study of violence against women. Vikas Publication. New Delhi.

Shah, Giri Raj. 1995. The Encyclopedia of Women Studies. Published in India by Gyan Publication House. New Delhi.

Tube, Annie. 1978. The Women Battering Syndrome. Association Paper . South Western Sociological Association. 